\title{
Using Authentic Materials in the Foreign Language Classrooms: Teacher Attitudes and Perceptions in Libyan Universities
}

\author{
Abdulhakim M. Belaid (Corresponding author) \\ Doctoral Scholar, University of Limerick, Ireland \\ Email: hakimbelaid@gmail.com
}

\author{
Dr. Liam Murray \\ Lecturer, School of Languages Literature Culture and Communication \\ University of Limerick, Ireland \\ Email: Liam.Murray@ul.ie
}

Doi:10.5296/ ijld.v5i3.8218 URL: http://dx.doi.org/10.5296/ ijld.v5i3.8218

\begin{abstract}
Looking through English as a foreign/ second language EFL /ESL literature, the researcher found a large body of references encouraging the idea of exploiting authentic materials in the process of language teaching. Such strong and positive attitudes toward using such materials could be attributed to the many advantages in improving and developing learners' language proficiency. Moreover, authentic materials work on intensifying and developing learners' second language motivation. The current paper is an attempt seeking to recognize deeply and understand the Libyan EFL teachers' perceptions, attitudes and reactions toward using authentic materials in teaching English within Libyan state universities. EFL teachers from Azzaytuna; Azzawia; Al-Merghib; and Tripoli Universities participated in the current study. The results revealed that most EFL teachers hold positive attitudes to using authentic materials in language teaching. Some EFL teachers furthermore, emphasised on their regular use of the materials in their language classes, which would positively reflect on learners' language proficiency.
\end{abstract}

Keywords: Authentic materials, EFL in Libya, criteria, and sources of authentic materials 


\section{Introduction}

Since the 1970s, there has been an increasing incorporation of communicative approaches in the process of language teaching, which would yield better results in developing the learners' learning skills. One of the main aspects of such communicative movements is the emphasis on communication rather than forms and structures in L2 learning. That was an obvious insistence towards using the materials mirrors language utilized in the real world. Such an insistent was on teachers and curriculum designers for including more like materials, which reflect the everyday life language inside language classes. Additionally, there has been an endless argument from many researchers and scholars to integrate authentic materials because of its potentials in bridging the enormous gap between classrooms used materials and the real world. A significant aim of incorporating authentic materials is enhancing students L2communicative competence. There is an urgent need to prepare EFL learners for real life communications at the current time than three decades ago. As a consequence, EFL teachers in Libya should and must use authentic materials in EFL classes to help their students be better L2 speakers. The current study is an attempt to explore deeply the teachers' attitudes and reactions within Libyan Universities to using authentic materials in their FL classes, which would assist the current researcher designing suitable materials in subsequent stages.

\subsection{Literature Review:}

Several definitions of the term authenticity and authentic materials have been given in the field of language teaching. One shared element among all such definitions as is given by Kilickaya (2004) 'exposure to the real usage of the everyday life language', (p.1) and how native speakers use for their daily lives purposes. Kilickaya, (2004) has also indicated that something in common in all definitions of authentic materials is "exposure to real language and its use in its own community" (p.1).

Bacon and Finnemann, (1990), for instance, defined authentic materials as texts produced by and intended for native speakers for non-pedagogical purposes. Polio (2014) expresses the same feeling toward authentic materials, in which she stated that despite the many definitions of authentic materials, they are not created for educational language purposes. Authentic materials are designed for real-life goals and native speakers' communications. Also, she refers to spoken and written materials as samples of authentic materials. Kramsch, (1993), presented another definition in which she emphasized the non-pedagogical communication, the same as was given by Bacon and Finnemann, (1990). Rogers, (1988), refers to the quality and suitability of goals, objectives of the materials to learner needs and interests and their relationship to the real world.

In the present paper, Kramsch's and Bacon and Finnemann' definitions of authentic materials will be adopted and used in here, mainly, because they differentiate between materials produced by native speakers, whereas, the others are not. 


\subsection{The influence of authentic materials on EFL learners}

Since the late 1980s, the inclusion of authentic materials has taken its firm place in EFL classes, and such usage has yielded an endless debate in the field of language teaching. Despite all such discussion, the effectiveness of authentic materials has been uninterruptedly recognized, and language teachers worldwide prefer to use them rather than traditional textbook materials. There have been many empirical studies conducted before which proved the enormous positive results gained by language learners, who have had opportunities for interacting with authentic materials. In addition, many studies revealed that the four language skills are improved through using authentic materials, (Thanjaro, 2000; Kilickaya, 2004; Al-Musallam, 2007; 2009; Miller, 2005; Otte, 2006; and Gilmore, 2007). Harmer (1991), for instance, states that the use of authentic materials would improve and develop the learners' listening and reading skills in the target language, despite the heavy use of textbook materials. Bacon \& Finnemann, (1990), clarified that authentic materials would improve the learners' reading skills through presenting new vocabulary and expressions to language learners.

Furthermore, using authentic materials carries with it enhancing non-linguistic advantages. Researchers, in this regard, argue for the motivating potential of authentic materials, (Kilickaya, 2004; Zoltan, 2010; Murray et.al 2011; Thanajaro, 2000; and Mishan, 2005) which is essential for successful L2 learning. Guariento and Morley (2001), for instance, state that authentic materials are significant since they intensify and increase learners' learning motivation. Moreover, Kilickaya (2004) claims that using authentic materials increase and develop learners' motivation because such materials offer students a feeling that they are learning the real language. McNeil (1994) agrees with Kilickaya's (2004) claims in that authentic materials grant learners such a sense. Otte (2006) indicated that student motivation develops through using such materials in language teaching. Thanjaro, (2000) as well, observed an improvement in learners' self-satisfaction and motivation after using authentic materials, (texts) inside classrooms. Evidently, using authentic materials develops and enhances not only L2 proficiency, but also non-linguistic factors considered essential for successful language learning. Having discussed the significance of authentic materials, one should wonder from where such materials are obtained.

Despite the existence of some disadvantages, as may be concluded, the advantages of authentic materials are more than disadvantages. Integrating authentic materials in language classes will bring lively educational atmospheres and would return better practical learning results. The following section addresses significant sources of authentic materials, which EFL teachers can make use of in the process of L2 material selection.

\subsection{Sources of Authentic Materials}

There are many sources of authentic materials in the current time, of which teachers and language learners can make use. With such a globalized era, authentic materials become more accessible and easy to access than twenty years ago. Many researchers and scholars such as (Genhard, 1996; Berardo, 2006; Ianiro, 2007; Tamo, 2009; Jordan, 1997; Kilickaya, 2004; and Hedge, 2000) have referred to the many sources of authentic materials such as printed 
materials, like newspapers, magazines, brochures, novels, short stories, and audio-visual materials as TV and radio programmes, movies, songs, and even YouTube films. However, the most significant source is 'the Internet'. All materials above can be easily obtained by using the internet, and such materials are continuously updated. Some of these sources are updated on daily basis, such as magazines, newspapers, TV and Radio programmes. Another significant issue is the differences between authentic and non-authentic materials, which is discussed in the next section.

\subsection{Authentic vs. non-authentic materials:}

Several dissimilarities can be found between authentic and non-authentic (textbook) materials, and that many scholars and researchers have referred to such differences, (Tomlinson, 2012; Mishan; 2005; Adams, 1995; Miller, 2003; and Gilmore, 2007). A unique and distinguishing feature of authentic materials is that they are produced for real communication purposes; whereas non-authentic ones are specially prepared for educational ones. Another noteworthy difference is the merits of authentic materials in improving and developing communicative abilities of language learners, while non-authentic materials put an emphasis on language forms, and structures. Gilmore (2007) for instance, stated that textbook materials frequently fail to develop learners' communicative competence because they are mostly organized around a graded structured syllabus with lexico-grammatical features sequenced according to perceived difficulty. Another key difference is the acceptance of false starts. Authentic materials contain incomplete sentences, pauses and false starts, whereas, non-authentic materials are accurately, and false free prepared. Authentic materials qualify language learners for the real use of language outside of classroom setting while non-authentic materials prepare students for learning grammar, spelling, and even pronunciation. The chief difference between authentic and non-authentic artificial materials is also in the idea of naturalness. The former is naturally presented as it happened from their original sources while the latter is purposefully prepared for pedagogical aims.

\section{The EFL in the Libyan context}

All over the country, the educational system is comprehensive from primary, moving to secondary and then to a higher or university level, and the right to education was ensured post the 1969 uprising. Within the primary level, the educational programme is nine years during which learners study various subjects, and English is one of them. In the secondary stage, students study different topics, and from year two, they have to specialise in either a literary or a science section, and in both English is a compulsory subject. There are moreover, some intermediate-centres specialised in teaching various vocations, which students can join after completing preparatory and secondary stages, and would qualify them for the labour force in the Libyan society. English within such vocational centres is taught English as for specific purposes $(E S P)$, in which are specialist vocations taught within those centres.

During the 1980s, and more from 1986 to 1992, The English language teaching was banned from the Libyan curricula in all the aforementioned educational stages. A political decision was behind eliminating English. In the year 1992, Libyan authorities were permitted to reuse English as a school subject in the curricula, and Libyan EFL learners found themselves being 
exposed to L2 after a period of 10 years of banning. Consequently, EFL learners in different sectors encountered many difficulties. Most of which are related to learners' failure to understand and learn English language as it is planned.

According to the Ministry of Education, 2007, the educational system has been reorganised to become as following: the primary stage 6 years; preparatory stage 3 years; secondary stage 3 years; and finally university or higher stage, which is between 4 to 6 years according to the field of specialisation. During all these phases, English is taught as a compulsory subject, and it has been observed that EFL learners are facing many problems particularly in the university level. EFL learners at English departments continuously criticize materials used by their EFL teachers, in which such materials do not meet their immediate language needs and interests. Such criticism from students could be attributed to the heavy dependence on traditional materials in L2 teaching, which hardly reflect the everyday life usage of English as in native speaker communications. The present paper is an attempt to explore the EFL teachers' perceptions, attitudes and reactions to using authentic materials in EFL teaching within the Libyan universities.

\subsection{Purpose of the study:}

The principal aim of the current study is to know the EFL teacher attitudes and reactions toward using authentic materials in language teaching. The present study attempts to find answers to the following questions:

1- What are the EFL teachers' attitudes toward using authentic materials in language classes at the Libyan university context,

2- In case of using such materials, what criteria do they apply in selecting authentic materials for their students?

3- What sources are available for EFL teachers in obtaining authentic materials?

4- Which level is appropriate for presenting authentic materials?

\subsection{Methodology:}

Some EFL teachers working at different Libyan universities had been approached to participate in the current study. All participants were Libyans EFL teachers with different teaching expertise, ranged between 2 into 25years within the academic context. Some of those teachers were working on their doctoral programmes during the time of the study, and contacted through their personal emails.

\subsection{Procedures and instruments:}

Only a questionnaire was used in the process of data elicitation for the present paper. For more details and a full outline of the survey, please see (Appendix A). The questionnaire was distributed to fifteen EFL potential teachers to enquire about their attitudes and reactions toward using authentic materials in teaching The English language within their language classes. However, there were only ten EFL teachers who actually returned the questionnaire. Ten questions included, in which some were YES/No questions; others were multiple-choice 
questions. The participant teachers were given the opportunity to select more than one option in certain issues. In addition, they were given between 3 to 5 days to finish and return their questionnaires. The researcher's personal emails and contact information were provided in case for more details needed.

\section{Results and discussion}

As mentioned before, the current study worked on finding out EFL teachers' perceptions, attitudes, and reactions toward using authentic materials in an EFL third level context. To be able to answer the given study questions, a questionnaire was used and distributed online to a number of EFL Libyan teachers. Some of those teachers were working on their doctoral programmes; others were already in-service EFL teaching in different Libyan universities. The questionnaire itself consisted of ten items, the aims of which were to seek the participants' attitudes and reactions and at the same time to determine potential answers to the given questions. As mentioned above, in certain issues, teacher participants were given the opportunity to select more than one answer of the given options.

According to the elicited results, there has been an overall indication among EFL Libyan teachers on the merits of using authentic materials in L2 teaching-learning process. All seven teachers indicated their preference for using such materials in language classes, which appeared clearly through their selection of the item yes in the first question. As a consequence, all teacher participants ignored the next question, reasons for not using authentic materials in EFL teaching. Results here build upon to what Soliman (2013) findings at the University of Benghazi, in which he found that language teachers prefer using authentic materials in their reading classes.

In the third question, reasons for using authentic materials, participants' answers varied here. Some of them selected that to expose their students to the everyday life language, others chosen to develop their language skills, and the smallest number selected item c, to develop their learning motivation. The overwhelming majority of teachers selected the first item, indicating their use of authentic materials to expose their language learners to the everyday life language. In this regard, Tomlinson (2012) stated that several researchers argue that: “... authentic materials can provide meaningful exposure to language as it is actually used, motivate learners and help them develop a range of communicative competencies and enhance positive attitudes towards the learning of a language" (p.161). However, some selected the three items a, b,c, together indicating support of all the given reasons.

In analysing the EFL teachers' responses, it is obvious that all of them prefer to use authentic materials in their language classes for different purposes. The prominent one is to expose students to the everyday life language. Some of them selected the three given answers namely to develop daily language; learning skills, and learning skills, which is an interesting findings here. They are very aware of the significance of authentic over other traditional textbook materials in enhancing their students' language abilities. Results found are in a consistent with many other previously conducted studies, (Soliman, 2013; Al-Musallam, 2007; Thanjaro, 2000; Otte, 2006; and Miller, 2005). Moreover, results are inconsistent with the common element of almost all definitions of authentic materials, "exposure to real language and its use 
in the own community" Kilickaya, (2004).

The same option was given to study participants to select more than one answer to question four, which asked about their preferable classes of using authentic materials. The majority of teachers preferred the listening classes for using authentic materials; the speaking and reading classes appeared second as preferable classes for using authentic materials. The writing classes emerged as the last choice for using authentic materials with teacher participants.

Concerning introducing authentic materials, question five inquired about which level EFL teachers prefer to use such materials in language teaching. The majority of them selected the intermediate level as suitable for presenting materials; results are in accordance with what Kilickaya, 2004; Kim, 2000 and Al-Musallam, 2007 have already stated. Whereas, some language teachers selected beginner level as suitable for presenting authentic materials, which agrees with Miller (2005) and McNeil (1994). They both referred to the possibility of using authentic materials even with lower level learners. Great attention may be should be paid to the suitability of materials to learners' learning levels, as Day (2004) stated that: "teachers should use materials that are appropriate for the linguistic abilities of their students" (p.110). Language teachers should pay attention to materials suitable for their levels and ensure enhancing their interest in L2 learning.

The next question enquired about what criteria EFL teachers apply in selecting authentic materials for their students. Six answers were given: course objectives; students' needs and interests; students' gender; students' language level; and cultural differences. Most teachers selected all of the given answers, but they ignored the students' gender as a criterion in selecting materials for their students. Results agree with what McGrath, 2002; Berardo, 2006, Bacon and Finneman, 1990; Lee, 1995; Mishan, 2005 and others have all referred to using such principles in materials selection. Only one EFL teacher selected gender as the basis for selecting authentic materials for his students. This could be interpreted to religious reasons, in which certain types of authentic materials could be used and discussed with male rather than female EFL learners in a Muslim society as Libya.

The availability of materials sources was another significant question addressed to the study participants. Different types of both categories of authentic materials were given to question seven. The internet and printed materials such as magazines and newspapers were the most accessible authentic material sources to Libyan EFL teachers. One teacher selected English television programmes, and another one selected a variety of all sources as available to him. Contrary to Al-Musallam (2007) study in Saudi context, in which she found that EFL teachers TV/Video are the most commonly used sources of authentic materials. The internet appeared second and printed materials as magazines and newspapers appeared third. Results of the current study are consistent with what Berardo (2006) stated on the significance of Internet as a significant and continuously modernised source of materials: "Whereas newspapers and any other printed materials, e.g. textbooks date very quickly, the internet is continuously updated, more visually stimulating and being interactive..." (p.62) 
Question eight enquired about whether using authentic materials need specific training. Almost all teacher participants six out of seven agreed that using such materials required specific training. Only one EFL teacher said that he did not need any specific training.

Question nine addressed to those EFL teachers who stated their need for specific training to be able to use authentic materials in their language classes. The participant teachers selected more one option, and the most familiar selected are selecting activities; yearly workshops; and curricula adjustments. One experienced EFL teacher commented that: "intensive training sessions are essential". Findings here indicate that EFL teachers need assistance to be able to use authentic materials appropriately. Assistance could be in designing activities, or in curricula changes. Some insisted on holding training sessions every year, particularly for recently qualified lecturers.

The final question was an open-ended one, in which teacher participants were asked to express and or add any comments concerning the use of authentic materials in EFL Libyan context. One of the participant teachers stated that one of the problems that face teachers who want to use authentic materials in their classrooms is preparing activities and questions. This type of material is usually found without activities or issues, which add more work and responsibility on the teacher. Besides, making activities and writing questions are not an easy task that any teacher can handle.

The teacher refers to one of the disadvantages of authentic materials in EFL teaching. Time preparation on the side of teacher makes many teachers hesitant to use such materials in their classes. However, such a problem could be avoided by carefully selecting appropriate materials. Another EFL teacher emphasised that teachers should use authentic materials all the time. I have used authentic materials as a supplementary activity with my students in teaching them reading and speaking. I took pictures of different direction signs in streets, prices in shops, food menu in restaurants, then I displayed them in an attractive way using data show projector. Students look at them, read them and then work in groups to find out similar materials. Such activities were very efficient in motivating and activating my students' prior knowledge and developing critical thinking skills. Therefore, I'd highly recommend teachers to use authentic materials with their students to encourage them to develop their cognitive, practical and psychomotor skills.

Besides, EFL teachers could appoint their learners to collect as much materials as possible and select which are suitable and which are not. Doing so, would save much of the teachers' preparation time, and moreover, would reflect positively on their L2 learners' language acquisition.

\section{Conclusion}

The present study examined the EFL teacher perceptions, attitudes, and reactions toward using authentic materials within the Libyan third level context. The EFL teachers were deliberately selected from Libya, to help the researcher in covering the vast gap of appropriate and much-needed research literature on EFL acquisition in that country. The study participants were selected from different universities, University of Tripoli, 2; 


\section{Macrothink}

University of Azzawia, 2; Azzaytuna University 2; and one EFL teacher from Al-Merghib University. The elicited data showed that all EFL teachers, despite differences in their teaching experiences and academic degrees all fully advocated using authentic materials in language classes. Teachers referred to using authentic materials in different classes, and they mostly preferred the intermediate level of L2 competency in which to present such materials. Moreover, teacher participants recognize that using authentic materials would expose students to the everyday real language, as used in the daily life language. Principles such as course objectives, students' language levels, students' needs and interests were essential criteria in selecting materials for their students. Cultural differences between L1 and L2 were mentioned as a significant criterion in the process of material selection as well. Concerning the available sources, EFL teachers referred to The internet, and printed materials such as magazines and newspapers as the most significant of all the given sources. Furthermore, the teacher participants clarified two main items which require specific training: selecting activities; and curricula modifications. Some also referred to holding yearly workshops on how to use authentic materials as being needed in order to show innovative teaching approaches and how to use such methods in EFL teaching.

\section{Limitations of the current study}

Some limitations exist in the present study. The prominent one was that the number of participant EFL teachers only seven, however, this did produce much valuable data. Another one is the use of a questionnaire as the sole method of data elicitation. A replicate study could use other research instruments for a richer and more generalizable amount of data. Intermediate EFL teachers may need to be interviewed for a similar study to elicit their attitudes and reactions to using authentic materials.

\section{References}

-Kilickaya, F. (2004). Authentic materials and cultural content in EFL classrooms. The Internet TESL Journal, 10(7), 1-6.

-Bacon, S. M., \& Finnemann, M. D. (1990). A study of the attitudes, motives, and strategies of university foreign language students and their disposition to authentic oral and written input. The Modern Language Journal, 74(4), 459-473.

-Charlene Polio (2014) Using authentic materials in the beginning language classroom. Volume (18) issue (1) Clear News, Michigan State University

-Kramsch, C. (1993) FEATURE ARTICLE Language, culture, and voice in the Teaching of English as a Foreign Language

-Rogers, C. V., \& Medley, F. W. (1988). Language with a purpose: Using authentic materials in the foreign language classroom. Foreign Language Annals, 21(5), 467-478.

-Al-Musallam, E. I. (2009). College instructors' and learners' attitudes to authentic 
EFL reading materials in Saudi Arabia (Doctoral dissertation, King Saud University)

-Thanajaro, M. (2000). Using authentic materials to develop listening comprehension in the English as a second language classroom (Doctoral dissertation, Virginia Polytechnic Institute and State University)

-Otte, J. (2006). Real language to real people: a descriptive and exploratory case study of the outcomes of aural authentic texts on the listening comprehension of adult ESL students enrolled in an advanced ESL listening course. Dissertation Abstracts International, 67 (04), 1246B. (UMI No. 3212979)

-Miller, M. (2005). Improving aural comprehension skills in EFL, using authentic materials: an experiment with university students in Nigata, Japan. Unpublished master's thesis, University of Surrey, Guildford, UK.

-Gilmore, A. (2007). Authentic materials and authenticity in foreign language learning. Language teaching, 40(02), 97-118

-Musallam, A. (2007). Using Authentic Materials in the Foreign Language Classroom: Teachers' Perspectives in Saudi Arabia

-McNeill, A. (1994). What Makes Authentic Materials Different? The Case of English Language Materials for Educational Television. Papers presented at the Annual International Language in Education Conference, Hong Kong

-Tamo, D. (2009). The use of authentic materials in classrooms. Journal of LCPJ, 2(1), 74-78.

-Sally Ianiro, (2007) Authentic materials. Professional development Fact sheet, No (1), American Institute for Research

-Tricia Hedge, (2000) Foreign Language Study. OUP Oxford,

-Tomlinson, B. (2012). Materials development for language learning and teaching. Language Teaching, 45(02), 143-179.

-Adams, T. (1995). What Makes Materials Authentic? (ERIC Document Reproduction Service No. ED 391389

-Soliman, E. M. (2013). Libyan teachers' Attitudes and Believes Regarding the Use of EFL Authentic Materials within Reading Lessons at Universities Levels in Libya. International Journal of Learning and Development, 3(5), Pages-121

-Kim, D. (2000). A qualitative approach to the authenticity in the foreign language classroom: a study of university students learning English in Korea. Texas Papers in Foreign Language Education, 5 (1), 189-205

-Richard R. Day, R. R. D. (2004). A critical look at authentic materials. The Journal of Asia TEFL, 1(1), 101-114 
-Lee, W. (1995). Authenticity Revisited: text authenticity and learner authenticity. ELT Journal, 49 (4), 323-328

•McGrath, I. (2002). Materials evaluation and design for language teaching.

\section{Appendix A}

Questionnaire on the Use of Authentic Materials in Teaching EFL Lessons

Please fill in the following as appropriate

6. University

7. Years of experience in EFL teaching

1- Do you prefer using authentic materials in your EFL classes?

8. Yes,

9. No,

If your answer is 'No', please move on to question 2.

2- Why do you not prefer to use 'Authentic Materials' in your EFL classes?

a) Do not see it as relevant

b) Difficult to be used

c) Time consuming

d) Syllabus constraints

e) Other reasons

please mention

3- Why do you prefer to use authentic materials?

a) In order to expose students to everyday life language 
b) In order to develop their language skills

c) In order to develop their learning motivation

d) For other reasons,

please specify,

4- In which class(es) do you prefer to use them? ( You may tick more than one option)
a) Listening
b) Speaking
c) Reading
d) Writing

5- At which level would you use authentic materials?
a) Beginners
b) Intermediate
c) Advanced

6- In selecting authentic materials, what criteria would you follow?
a) Course objectives
b) Students'needs and interests
c) Students'gender
d) Students'language level
e) Cultural differences
f) Others,

7- What sources of authentic materials are available for you to use?
a) Internet
b) Radio
c) Television programmes 
d) Printed materials such as magazines and newspapers

e) A variety of all sources

f) Others, please specify,

8- Do you think using authentic materials need specific training?

10. Yes

11. No

12. If you have answered 'YES' to question '8', please proceed to question ' 9 ' below:

9- What kind of specific training do you need to be able to use authentic materials in an EFL classroom?
a) Selecting activities
b) Yearly workshops
c) Curriculum adjustments
d) Others

please

specify,

10-If you have any comments you would like to add, please feel free to mention them below

Thank you very much for taking the time to complete this questionnaire, it is highly appreciated

The Researcher 